Viena-Tuuli Vasara

\title{
MODERN FINNISH HISTORIOGRAPHY: THE SECOND WORLD WAR - NEW APPROACH TO OLD TOPIC
}

This review focuses on a highly relevant monograph of a young Finnish researcher Ville Kivimäki "Broken Minds. Battle for the Nerves of the Finnish Soldiers 1939-1945". In his work, the author is the first in the Finnish historiography to consider psychological trauma among Finnish soldiers during the Second World War. In the book, the attention is drawn not to political or economic issues of war, but to the specific problems of the ordinary soldiers - how they handled the new conditions of life at the front, the horrors of war and the psychological problems that might appear. It is analyzed separately how the Finnish armed forces treated this new phenomenon, in particular how the military psychiatrists tried to treat psychologically damaged soldiers. Kivimäki seeks not only to describe the overall situation. His goal is to identify the specific causes of the "crippled souls". Scientific research of V. Kivimäki is based on a broad documentary base - case histories of psychiatric hospitals, as well as documents from the archives of the Military medical unit of the armed forces of Finland, research papers of the military psychiatrists and memories of veterans, stored in the archives of the Finnish Literature Society and the People's Archive in Helsinki. Refs 11.

Keywords: Historiography, Second World War, Finland, Soldier Masses, Psychological Traumas, medical history, Military History.

\section{Виена-Туули Васара}

\section{СОВРЕМЕННАЯ ФИНСКАЯ ИСТОРИОГРАФИЯ: ВТОРАЯ МИРОВАЯ ВОЙНА - НОВЫЙ ПОДХОД К СТАРОЙ ТЕМЕ}

Обзор посвящен весьма актуальной монографии молодого финского исследователя Вилле Кивимяки «Искалеченные души. Борьба нервов в финской солдатской среде в 1939-1945 гг.». В своем труде автор впервые в финской историографии рассматривает вопрос психологических травм в среде финских солдат в годы Второй мировой войны. В книге внимание обращается не на политические или экономические проблемы войны, не раз поднимавшиеся, а на конкретные проблемы рядовых солдат - как они принимали новые условия жизни на фронте, ужасы войны, какие психологические проблемы у них могли появляться. Отдельно анализируется реакция командования: как в финских вооруженных силах относились к этому новому явлению, как, в частности, военные психиатры пытались лечить психологически травмированных солдат. Кивимяки стремится не просто описывать общую ситуацию, его цель - выявить конкретные причины появления «искалеченных душ». Научное исследование В.Кивимяки основано на широкой документальной базе - многочисленных эпикризах психиатрических больниц, а также документах Архива военно-медицинской части вооруженных сил Финляндии, научных статьях военных психиатров и воспоминаниях ветеранов, хранящихся в архиве Общества финской литературы и Рабочем архиве в Хельсинки. Библиогр. 11 назв.

Ключевые слова: историография, Вторая мировая война, Финляндия, солдатская среда, психологические травмы, история медицины, военная история.

In general, Finnish scientific literature dedicated to historical problems can be considered quite interesting. However, speaking about the current priorities here, researchers are usually limited to a number of special characteristic historical themes. Traditionally the most common theme in the Finnish historical environment is the study

Vasara Viena-Tuuli - Researcher, 49, Kulmakatu, Tampere, 33500, Finland; viena-tuuli@skinsaw.com

Васара Виена-Туули - исследователь, 33500, Финляндия, Тампере, Кулмакату, 49; viena-tuuli@skinsaw.com

() Санкт-Петербургский государственный университет, 2016 
of issues related to the participation of Finland in the Second World War. This research subject is also now one of the most preferred for the Finnish historians and the political and military history as a whole preserves its priority.

For example the following books can be considered as the most characteristic of modern scientific research of this area: M.Danielsbacka's "Faiths of the Prisoners of War: Soviet Prisoners of War in Finland 1941-1944" [Danielsbacka 2016]; P. Visuri's "Mannerheim's and Ryti's Hard Choices - The Decisions of the Finnish Leaders at the Turning Point of the Continuation War" [Visuri 2015]; A. Holmila's and S. Mikkonen's "Finland after the War: the Years of Fear, Bitterness and Hope 1944-1949" [Holmila, Mikkonen 2015]; T.Tepora's "Essence of War: the Beautiful and Ugly Winter War" [Tepora 2015]; L. Laaksonen's "Discord and Prestige: Mannerheim and Generals, Personal Relationships and Leadership" [Laaksonen 2014]; T. Keskisarja's "The Brutal Route to Raate: History of People in a Major Battle" [Keskisarja 2014] and M. Kulju's "The Lapland War 1944-1945" [Kulju 2013]. These trends in the Finnish historiography were marked very accurately in one of the Finland's leading historical journals in an article by a wellknown researcher K. Korhonen in the late 1970's [Korhonen, p. 263] as an aspiration for the general continuity of the Finnish historians to study the participation of Finland in the World War II, which clearly can be traced down to the present day. In this sense, it is understandable why the unusual monograph of a young researcher Ville Kivimäki "Broken Minds. Battle for the Nerves of the Finnish Soldiers. 1939-1945" [Kivimäki 2013] got a lot of attention in the Finnish scientific community. The book also received the most prestigious literary award of scientific literature in Finland "Tieto-Finlandia" in 2013. The basis of the monograph was based on the Kivimäki's doctoral thesis, which he defended in 2013 in the Academy of Åbo (Turku).

Indeed, this very serious and fundamental work introduces a completely new point of view to the part of the well-studied Finnish history, which deals with the World War II. It is shown very vividly in the very comprehensive book containing more than 470 pages of fine print that the war is not only heroism and deeds, but also concrete soldiers with their personal problems and, as a rule, wounded souls. The book reveals clearly that the war left deep psychological trauma among Finnish soldiers. In the period of the World War II, as indicated in the work, about 18,000 Finnish military servicemen (of which about 15700 in the period of the Continuation War 1941-1944) were hospitalized with a diagnosis of "mental illness" or "nervous system disorder". In other words, in wartime from 2 to $2.5 \%$ of the Finnish soldiers were for some time undergoing psychiatric treatment [Kivimäki 2013, p. 8-9].

Comprehended the data, the author set the task to look at the war from a nontraditional perspective. In his study, V. Kivimäki clearly wants to draw the attention not to the political, military or economic aspects of the participation of Finland in the war, but in particular, to the fate of ordinary soldiers who were severely affected by the war and became disabled. This approach cannot be considered absolutely new for the Finnish historiography, as there has already been attempts to understand what people involved in the war did "know and feel" [Baryshnikov 2015, p. 198-218]. However, the author of the monograph "Broken Minds" chose an entirely different object of study. He decided to examine in strictly professional manner how the war affected the ordinary soldiers, who were often doomed to suffer from severe mental traumas, which were caused by the horrors of daily life in the war. 
In this regard, V. Kivimäki can be considered the first historian to turn to the study of this topic. In that way his research opened the story so far remained untold, because earlier soldiers mentally ill as a result of the war were generally considered to be only deserters. Their mental illness was regarded as a manifestation of normal human frailty, which, of course, like in the army, also in the society, could cause only negative attitude of "blame and shame". Thus, the author of the study was the first Finnish historian who touched the unstudied research issues in Finland related to questions of military history of psychiatry. In addition, it can be considered characteristic that until the appearance of Kivimäki's research the given problem was generally regarded as a pure "medical issue". It had a research interest in Finland, not by historians, but medical doctors who were occupied in studying military neurosis and trauma during and immediately after the war. The first articles on mental disorders of soldiers and the results of their therapy appeared already at that time, but soldiers' mental health problems remained unaffected in the Finnish historiography.

The Finnish public raised the subject only in recent years, but it happened after most members of the war generation had already died. Obviously, their passing was also assisted by the fact that the soldiers with mental traumas were outsiders in the Finnish society, where during the war and in post-war period dominated the ideology of "home, religion and fatherland". This ideology was dominant also in the Finnish historiography. Approaching the disclosure of such a complicated and very sensitive topic, the author was able to attract large amount of documentary material to his extensive study. V. Kivimäki was able to analyze about 500 psychiatric hospitals' epicrises, as well as process the documents from the "Archive of the Finnish Defense Forces' Medical Unit", military psychiatrists' scientific articles and memories of the war veterans, stored in the "Archive of the Finnish Literature Society" and in the "People's Archives" in Helsinki. This allowed the recreation of a historically quite objective picture about what took place during the war.

In the first two chapters of his book, V. Kivimäki primarily tried to understand, who the soldiers were, whose frontline crosses usually lead to mental disorders, and how on that time the Finnish armed forces reacted toward this new phenomenon. Essential for the author became the analysis of the criteria on which the soldiers were sent from the front to psychiatric treatment, and what happened to those for whom symptoms of mental illness were confirmed, but who for some reason did not receive proper treatment. As a result, the author concludes that with the beginning of the "Winter War", doctors faced a very unusual phenomenon: in the field and military hospitals began to appear soldiers with no external injuries, with symptoms that often resembled a concussion. In colloquial language, such patients were called "jolted" (tärähtäneet, from aivotärähdys - concussion). Finnish military medicine was completely unprepared for this. However, already in the beginning of January 1940 Military's medical service realized the seriousness of the "war neurosis".

As a result, new psychiatric units were opened in hospitals, and finally during the completion of the "Winter War" (March 1940) there were about 700 hospital beds (in the end of the "Continuation War" nearly 1,800 places, including in the field hospitals), which was a record for the war years. Nevertheless, the saddest fact, as the author notes, is that shortly after the end of the "Winter War", organization of mental health was abolished and most of the soldiers deprived of medical care, especially in cases when the first symptoms of mental illness started only after the end of the military operations, or even after demobilization. However, as Kivimäki states, to the beginning of the "Continuation 
War" military medical service was already much better prepared to address this problem, but at the same time also the number of Finnish soldiers in need of such specific aid was dramatically increased [Kivimäki 2013, p. 395-396].

In the third chapter, the researcher explores in detail the moral stamina of soldiers in wartime conditions. At front adaptation problems related to thoughts of family, depression and despair, alcoholism, and general fatigue became frequent. However, psychiatric care was provided only in the most difficult cases, that is, when soldiers had lost all capacity and psychical equilibrium. This was affected also by the fact that the decision to seek psychological help by victims themselves was made with great difficulty [Kivimäki 2013, p.397].

The author reminds that after the war some Finnish military psychiatrists already expressed the view that the cause of soldiers' mental illness was probably the war, not the soldiers themselves. However, if the military psychiatrists traditionally asked a question why the soldiers at the front lost their mind, Kivimäki asks an opposite question: how did the soldiers manage to keep their sanity, the ability to think in the frontline conditions? Moreover, even if making an accurate conclusion about which of the soldiers were most prone to breakdown was hard enough, the author notes that the better the soldiers were adapted to the front environment; the lower was the likelihood of mental health problems. In wartime, soldiers created a special frontline identity closely linked to the military environment. An important factor was also the age of the soldiers [Kivimäki 2013, p. 398399].

In the final part of his research, analyzing the history of Finnish war psychiatry Kivimäki tried to figure out how the physicians really solved their main task — to diagnose and treat mental injuries that appeared among the soldiers. In addition, he briefly discusses the history of the field of psychiatry during the "Lapland War" (September 1944 - April 1945), and immediately after its completion, in particular, the question of the impact on the overall situation ideas about the possibility of obtaining the material compensation to the mentally traumatized soldiers that existed in the Finnish war psychiatry those years. However, special attention, which is very important, is given in the final part of the study to the question: why in the 1940's soldiers' psychiatric disorders were treated differently than other war traumas. Kivimäki has a quite critical attitude towards the effectiveness of the Finnish psychiatric treatment during the war and explicitly argues that the diagnoses of the Finnish military psychiatry were quite unsystematic and even "confused". As a result, only a small number of soldiers could return to duty after the psychiatric treatment to the front line if the war was still going on. Many problems remained relevant for former psychiatric patients in the postwar period [Kivimäki 2013, p. 401-402].

In general, in his work Kivimäki offers a completely new perspective on the history of not only military, but also the general psychiatry in Finland. It was important for the author to prove that by nature psychological disorders were a normal reaction to the extraordinary and, as a rule, appalling conditions of war. Such disorders were not signs of "abnormality" or not enough solid character, as they were perceived. Researcher seeks not simply to describe the overall situation, but above all to identify the specific causes of the "crippled souls". Though the scientist disadvantages Finnish war psychiatry repeatedly, he does not blame psychiatrists: in the "struggle of nerves", they did everything they could. In this regard, we can only support the views of the author of this unique research and emphasize that the special importance of his work lies in the fact that it is 
not addressed only to the fellow researchers, but also to the general reader. More easily becomes understood the history of its country, the war generation's history, history of the "silent people" as they are often called in Finland - former soldiers, who the war changed forever.

\section{References}

Baryshnikov V.N. Finliandiia na poroge rozhdeniia «Vtoroi Respubliki»: 1944 god i ego znachenie dlia finskoi istorii [Finland on the Threshold of the Birth of the Second Republic: 1944 and its Significance for the Finnish History]. Trudy kafedry istorii Novogo i noveishego vremeni [Proceedings of the Department of Modern and Contemporary History], 2015, no. 13, pp. 198-218. (in Russian)

Danielsbacka M. Sotavankikohtalot: Neuvostovangit Suomessa 1941-1944 [Faiths of the Prisoners of War: Soviet Prisoners of War in Finland 1941-1944]. Helsinki, Tammi [Oak Corporation] Publ., 2016, 350 p. (in Finnish)

Holmila A., Mikkonen S. Suomi sodan jälkeen: pelon, katkeruuden ja toivon vuodet. 1944-1949 [Finland After the War: the Years of Fear, Bitterness and Hope. 1944-1949]. Jyväskylä, Atena Publ., 2015, 265 p. (in Finnish)

Keskisarja T. Raaka tie Raatteeseen: suurtaistelun ihmisten historia [The Brutal Route to Raate: History of People in a Major Battle]. Helsinki, Siltala Publ., 2014, 329 p. (in Finnish)

Kivimäki V. Murtuneet mielet. Taistelu suomalaissotilaiden hermoista. 1939-1945 [Broken Minds. Battle for the Nerves of the Finnish Soldiers. 1939-1945], Helsinki, Werner Söderström Publ., 2013, 475 p. (in Finnish)

Korhonen K. Suomen ulkopolitiikan ja kansainvälisen aseman tutkimuksesta [Finland's Foreign Policy and International Status of Research]. Historiallinen Arkisto [Historical Archives], 1978, no. 71, pp. 259666. (in Finnish)

Kulju M. Lapin sota 1944-1945 [The Lapland War 1944-1945]. Helsinki, Gummerrus Publ., 2013, 390 p. (in Finnish)

Laaksonen L. Eripuraa ja arvovaltaa: Mannerheimin ja kenraalien henkilösuhteet ja johtaminen [Discord and Prestige: Mannerheim and Generals, Personal Relationships and Leadership]. Jyväskylä, Docendo Publ., 2014, 495 p. (in Finnish)

Tepora T. Sodan henki: Kaunis ja ruma talvisota [Essense of War: the Beautiful and Ugly Winter War]. Helsinki, WSOY Corporation Publ., 2015, 372 p. (in Finnish)

Uus-Eskola M. Ville Kivimäen sotilaan psyykeä kuvaava Murtuneet mielet voitti Tieto-Finlandijan (Ville Kivimäki's View's on Psychology of the Finnish Soldiers "Broken Minds" Won the Tieto-Finlandia Award). Helsingin Sanomat. 21.11.2013. Available at: http://www.hs.fi/kulttuuri/a1385003137715 (accessed 01.11.2015). (in Finnish)

Visuri P. Mannerheimin ja Rytin vaikeat valinnat - Suomen johdon ratkaisut jatkosodan käännekohdassa [Mannerheim's and Ryti's Hard Choices - The Decisions of the Finnish Leaders at the Turning Point of the Continuation War]. Jyväskylä: Docendo Publ., 2015, 399 p. (in Finnish)

For citation: Vasara V.-T. Modern Finnish historiography: the Second World War - new approach to old topic. Vestnik of Saint-Petersburg University. Series 2. History, 2016, issue 2, pp. 156-160. DOI: $10.21638 / 11701 /$ spbu02.2016.213

Для цитирования: Vasara V.-T. Modern Finnish historiography: the Second World War new approach to old topic // Вестн. С.-Петерб. ун-та. Сер. 2. История. 2016. Вып. 2. С.156-160. DOI: $10.21638 / 11701 /$ spbu02.2016.213 